\author{
Renata Szczepanik* (iD https://orcid.org/0000-0002-7443-0463 \\ Uniwersytet Łódzki \\ e-mail: renata.szczepanik@now.uni.lodz.pl
}

https://doi.org/10.25312/2083-2923.19/2021_07rsz

\title{
Integrowanie rodziny przez rodziców osób problemowo pijących alkohol na rzecz pokonywania kryzysu
}

\begin{abstract}
Streszczenie: Badania przedstawione w artykule dotyczą redukowania szkód wynikających z nałogowego picia alkoholu i hamowania rozwoju uzależnienia bez pomocy wyspecjalizowanych instytucji. Analizie poddano doświadczenia rodziców (dorosłych) dzieci pijących alkohol problemowo, którzy podejmują działania na rzecz pokonywania kryzysu w oparciu o siły tkwiące w bliskości i spójności rodziny oraz konsolidacji jej członków na problemie. Materiał empiryczny pochodzi z wywiadów autobiograficznych z rodzicami, których dziecko pije alkohol problemowo. Perspektywa symbolicznego interakcjonizmu pozwoliła na wyjście poza medyczny i psychologiczny model interpretowania tego, co się dzieje w rodzinie z problemem uzależnienia. Wyniki badań pokazują, że tym, co integruje rodziny, jest skrywanie tajemnicy (lęk przed stygmatyzacją). Efektem ubocznym (spillover effect) jest tu rodzinna mobilizacja, poprawa komunikacji i poczucie sprawczości. Niezamierzonym pozytywnym skutkiem działań rodziców w obrębie rodziny i z użyciem jej sił na rzecz pomocy dziecku problemowo pijącemu alkohol jest pogłębiona refleksja nad swoim rodzicielstwem oraz - paradoksalnie - poczucie zbliżenia do dziecka i poprawienie $\mathrm{z}$ nim relacji.
\end{abstract}

Słowa kluczowe: problemowe picie alkoholu, rodzina, kryzys, rodzice, efekt spillover

\footnotetext{
* Renata Szczepanik - profesorka na Wydziale Nauk o Wychowaniu Uniwersytetu Łódzkiego w Katedrze Pedagogiki Społecznej i Resocjalizacji. Członkini Polskiego Towarzystwa Kryminologicznego im. Stanisława Batawii oraz członkini Sekcji Pedagogiki Resocjalizacyjnej przy Komitecie Nauk Pedagogicznych PAN. Jej zainteresowania naukowe obejmują problemy, które określa mianem „kryminologii zza krat” (convict criminology), rehabilitacji społecznej osób łamiących normy prawne i obyczajowe oraz metodologii badań terenowych.
} 


\section{Wprowadzenie}

Kiedy przedmiotem rozważań są problemy rodziny związane z nadużywaniem alkoholu przez jednego z jej członków, to zwykle omawiane są procesy dezintegracji i zaburzeń realizacji podstawowych funkcji. Bardzo dobrze udokumentowane w piśmiennictwie naukowym są także różnorodne straty i rozległe szkody, jakie ponoszą dzieci i współmałżonkowie (zwłaszcza żony) ${ }^{1}$. Dominują opracowania o wadliwej adaptacji do problemowego picia alkoholu przez ojca czy partnera życiowego, a szczególne zainteresowanie badaczek i badaczy budzą takie kategorie, jak współuzależnienie czy syndrom Dorosłego Dziecka Alkoholików (DDA). Również zagadnienia odzyskiwania równowagi społecznej i zdrowia psychicznego ofiar szkodliwego picia $\mathrm{w}$ rodzinie zajmują istotne miejsce w szerokim i różnorodnym piśmiennictwie psychologicznym ${ }^{2}$.

W pierwszej kolejności wiedza o tych zjawiskach pochodzi od osób (zwłaszcza kobiet i dzieci) biorących udział w terapiach, w trakcie których dochodzi do wyzwalania się z uwikłania w problemy alkoholowe męża czy ojca. O wiele rzadziej natomiast podnoszone są zagadnienia funkcjonowania społecznego osób, które radzą lub poradziły sobie ze szkodliwym piciem bliskich członków rodziny bez wsparcia terapeutycznego czy pomocy psychologicznej. Nie znaczy to jednak, że takich rozważań nie ma w ogóle. Przykładowo analizowane są losy dzieci, które stereotypowo skazywane bywają na porażkę życiową (na przykład z powodu pochodzenia $\mathrm{z}$ tak zwanych rodzin alkoholowych), a fenomen „poradzenia sobie mimo wszystko” opisywany jest w piśmiennictwie naukowym jako prężność psychiczna (resilience) ${ }^{3}$.

${ }^{1}$ Na przykład: C. Hurcom, A. Copello, J. Orford, The family and alcohol: Effects of excessive drinking and conceptualizations of spouses over recent decades, "Substance Use \& Misuse" 2000, No. 35(4); A. Karasowska, Krzywdzenie dzieci w rodzinie alkoholowej, „Dziecko Krzywdzone. Teoria, badania, praktyka” 2004, nr 3(3); P.S. Keller, E.M. Cummings, P.T. Davies, P.M. Mitchell, Longitudinal relations between parental drinking problems, family functioning, and child adjustment, "Development and Psychopathology" 2008, No. 20(1); K. Gąsior, Czynniki zagrażajace rozwojowi dzieci w rodzinie z problemem alkoholowym na przykładzie Dorostych Dzieci Alkoholików, „Alkoholizm i Narkomania” 2008, nr 3; L. Cierpiałkowska, M. Ziarko, Psychologia uzależnień - alkoholizm, Wydawnictwa Akademickie i Profesjonalne, Warszawa 2010; I. Grzegorzewska, L. Cierpiałkowska, Pozytywna i negatywna adaptacja dzieci i młodzieży rodziców uzależnionych od alkoholu, „Alkoholizm i Narkomania" 2015, nr 28(4); I. Niewiadomska, S. Fel, Formy przystosowania młodzieży w rodzinie z problemem alkoholowym, „Zeszyty Naukowe KUL”, 2015, nr 58(4); L. Cierpiałkowska, I. Grzegorzewska, Dzieci alkoholików w perspektywie rozwojowej i klinicznej, Wydawnictwo Naukowe UAM, Poznań 2016; R. Szczepanik, K. Okólska, Forgotten parents of alcohol dependent adults. Zapomniani rodzice (dorosłych) dzieci uzależnionych od alkoholu, „Alcoholism and Drug Addiction/ Alkoholizm i Narkomania” 2018, nr 31(4).

${ }^{2}$ R. Szczepanik, K. Okólska, dz. cyt.

${ }^{3} \mathrm{~W}$. Junik, Teoretyczne i empiryczne podstawy wzmacniania rezyliencji (resilience) u dzieci z rodzin z problemem alkoholowym, „Dziecko Krzywdzone. Teoria, badania, praktyka” 2012, nr 11(3); por. I. Grzegorzewska, L. Cierpiałkowska, Pozytywna..., dz. cyt. 
Na łamach piśmiennictwa naukowego trudno znaleźć analizy, w których podkreśla się problematykę samoleczenia (i samowyleczenia) ${ }^{4}$ w kontekście konstruktywnego udziału rodziny w zmaganiu się z nałogiem ${ }^{5}$. Jako że dominującą perspektywą analizowania zjawiska wychodzenia $\mathrm{z}$ nałogu alkoholowego jest psychologiczna $\mathrm{i}$ terapeutyczna, to niewiele wiadomo o pokonywaniu nałogu „własnymi siłami”. A przecież niektóre badania donoszą, że nawet $25 \%$ osób spełniających diagnostyczne kryteria uzależnienia od alkoholu pokonuje je bez tradycyjnych form wsparcia instytucjonalnego czy pomocy psychologicznej. Wygląda więc na to, że pokonywanie nałogu alkoholowego jest możliwe bez specjalistycznej pomocy psychologa czy terapeuty. Jak piszą Justyna Klingemann i Harald Klingemann: „[...] Każda indywidualna zmiana zachowania odbywa się w specyficznym kontekście społecznym: odniesienie sukcesu jest tym bardziej prawdopodobne, jeśli towarzyszy mu zmiana stylu życia na taki, w którym zachowania ryzykowne tracą atrakcyjność i gdy jednostka może liczyć na wsparcie przyjaciół i rodziny"6.

Badania własne przedstawione $\mathrm{w}$ dalszej części artykułu nawiązują właśnie do zagadnienia pokonywania nałogu bez udziału instytucjonalnego wsparcia terapeutycznego, za to przy znaczącym udziale rodziny. Problemy te przedstawię, opisując doświadczenia rodziców (dorosłych) dzieci pijących alkohol problemowo. Celem jest analiza działań rodziców podejmowanych na rzecz pokonywania kryzysu w oparciu o siły tkwiące w bliskości i spójności rodziny.

Przyjęcie przeze mnie perspektywy socjopedagogicznej oznacza, że cel ten nie jest osiągany poprzez zidentyfikowanie oraz zinterpretowanie doświadczeń rodzicielskich za pomocą kategorii psychologicznych czy terapeutycznych (adaptacja do sytuacji stresu, współuzależnienie itp.). Ramy teoretyczne interpretacji wyznaczają założenia teorii symbolicznego interakcjonizmu. Przedmiotem analiz nie jest więc to, co przeżywają rodzice, ale to, w czym uczestniczą oraz jakie definicje sytuacji przyjmują i odpowiednio do tego jak reagują.

Opisując doświadczenia rodziców, postaram się pokazać, co się może zadziać w rodzinie, która podejmuje pracę nad osłabianiem rozwoju uzależnienia jednego ze swoich członków bez wsparcia instytucji i opierając działania wyłącznie na własnych siłach. Co powoduje, że rodzina decyduje się (i solidarnie wspiera w takiej decyzji „alkoholika”) pokonać problem w zaciszu środowiska domowego i z udziałem sił wyłącznie wtajemniczonych członków? Na czym polega i jak przebiega wspieranie członka rodziny w pokonywania nałogu przez najbliższych?

${ }^{4}$ J.I. Klingemann, „Ja muszę Pani powiedzieć szczerze, że o tych problemach to nikt nie wiedział..." Metody badania populacji ukrytych - przykład zjawiska samowyleczenia z uzależnienia, „Prace Instytutu Profilaktyki Społecznej i Resocjalizacji” 2010, nr 16.

${ }^{5}$ R. Szczepanik, Rodzice osób pijących alkohol problemowo. O ambiwalencji pomocy, Wydawnictwo Uniwersytetu Łódzkiego, Łódź 2020.

${ }^{6}$ J. Klingemann, H. Klingemann, Czy terapia jest koniecznością? Samowyleczenia a system lecznictwa, [w:] G. Świątkiewicz (red.), Terapia uzależnień - metody oparte na dowodach naukowych, Wydawnictwa Uniwersytetu Warszawskiego, Warszawa 2013. 
Zanim szczegółowo opiszę problemy zawarte w pytaniach, krótko przedstawię różne rodzicielskie strategie niesienia pomocy (dorosłemu) dziecku z problemowym piciem alkoholu, omówię sposób badania, scharakteryzuję materiał empiryczny oraz zaprezentuję wyniki badań.

\section{Rodzice wobec problemowego picia alkoholu ich (dorosłych) dzieci}

Co wiadomo o rodzicach dzieci, które w okresie dorosłości borykają się z problemowym piciem alkoholu? Okazuje się, że niewiele. Jeśli rodzice tacy pojawiają się w badaniach środowiska rodzinnego osób z uzależnieniem, to stanowią część grupy określanej pojemnym mianem „członków rodziny” czy „najbliższych krewnych”, zwykle uczestników różnorodnych terapii czy innych instytucjonalnych form pomocy. Najczęściej bowiem (choć oczywiście nie zawsze ${ }^{8}$ ) to za pośrednictwem instytucji lub w jej obrębie badaczki, badacze docierają do badanych. Pewnym wyjaśnieniem niedostatku badań poświęconych wyłącznie rodzicom może być to, że relatywnie rzadko szukają wsparcia psychologicznego dla siebie, a na pewno o wiele rzadziej niż żony/ partnerki życiowe czy dorosłe dzieci. Bywa, że jeśli trafiają do specjalistów, to poszukują pomocy dla swojego (dorosłego) dziecka. Ponadto są osobami w starszym wieku i nie godzą się na długotrwałą terapię̧9

Pozostałe przyczyny niewielkiej liczby badań poświęconych w całości tym rodzicom tkwią w trudnościach metodologicznych innych niż organizacja próby badawczej. Jeśli nawet uda się dotrzeć do rodziców innymi sposobami niż za pośrednictwem instytucji, to okazuje się, że są to osoby, które niechętnie dzielą się swoimi przeżyciami i mają opory w opowiadaniu o problemach rodzinnych ${ }^{10}$. Powodowane jest to lękiem przed negatywną oceną społeczną oraz dramatyzmem doświadczeń i niechęcią do rozbudzania swoich emocji szczególnie podatnych na ból. Obawy rodziców osób z etykietą „pijaka” czy piętnem „alkoholika”, a zwłaszcza matek, związane są ze stereotypami społecznymi. Wzbudzaniu poczucia winy i obarczaniu ich odpowiedzialnością za zaburzone zachowania dorosłego dziecka sprzyjają opresyjno-kulturowe ideały macierzyństwa i specyficzna kultura obwiniania matek, a także praktyka terapeutyczno-diagnostyczna ${ }^{11}$.

${ }^{7}$ R. Szczepanik, K. Okólska, dz. cyt.

${ }^{8}$ L.A. Benishek, M. Carter, N.T. Clements, C. Allen, K.E. Salber, K.L. Dugosh, Psychometric assessment of a self-administered version of the Significant Other Survey, "Psychology of Addictive Behaviors" 2012, No. 26(4).

${ }_{9}$ R. Szczepanik, Rodzice..., dz. cyt.

10 Tamże.

11 R. Szczepanik, Na mapie rodzicielskich doświadczeń: matki i ojcowie osób z piętnem wykolejenia społecznego, „Resocjalizacja Polska” 2021, nr 2. 
$\mathrm{W}$ rezultacie badań jakościowych ${ }^{12} \mathrm{z}$ udziałem kilkudziesięciu rodziców osób, które nałogowo i szkodliwie piją alkohol, udało się wyłonić trzy grupy. Podziału tego dokonano ze względu na rodzaj angażowania się i sposób radzenia sobie z trudnościami życiowymi. Mowa o rodzicach, którzy szukają pomocy w wyspecjalizowanych instytucjach, takich, co „walczą" z problemem swojego dziecka w osamotnieniu, i w końcu tych, którzy wykorzystują w pokonywaniu problemów wyłącznie zasoby tkwiące w rodzinie. W dalszej części krótko omówię te trzy grupy.

Pierwszą grupę rodziców stanowią ci, którzy korzystają z pomocy specjalistycznej różnych instytucji. Ich doświadczenia są najlepiej rozpoznane z powodu bezpośredniej dostępności oraz możliwości rekonstruowania ich problemów w badaniach z udziałem specjalistów. Przyjrzenie się takim rodzicom przez pryzmat doświadczeń terapeutów pozwoliło Gabrieli Dobińskiej i Angelice Cieślikowskiej-Ryczko wyłonić kilka typów:

- rodzica w burzy, który „zwraca się po pomoc w poczuciu bezsilności, potrzebuje niejako ujawnić swoją bezradność i niemoc"13,

- rodzica w punkcie zwrotnym (odbijającego się od dna bezradności),

- rodzica w żałobie (na przykład z powodu utraty zdrowego dziecka),

- rodzica w ambiwalencji i dwugłosie (pełnego napięć wewnątrz swojej roli).

Szukanie przez rodziców pomocy w placówkach rozwiązywania problemów uzależnienia nacechowane jest wyraźną ambiwalencją potrzeb i oczekiwań. Z jednej strony pragną zdjęcia ciężaru odpowiedzialności, z drugiej jednocześnie chcą pozyskać wsparcie dla tej odpowiedzialności rodzicielskiej za (dorosłe) dziecko ${ }^{14}$.

Częściej matki niż ojcowie decydują się na pracę nad swoim rodzicielstwem i relacjami z dorosłym dzieckiem pod kierunkiem specjalisty. Praca ta rozpoczyna się od specyficznego „dyscyplinowania” miłości macierzyńskiej i nauki stawiania granic. Często jednak udział w terapii jest pozorny, a terapeuci sygnalizują „opór” rodzica przed taką pracą i niechęć do zmiany. Wspominana ambiwalencja powoduje, że matki są rozczarowane ofertą instytucji. Nie godzą się na etykietę pacjentki i osoby do „naprawy”, którą dostają w pakiecie pomocowym od instytucji i poradni zdrowia psychicznego, szczególnie jeśli placówki te opierają swoje programy na tradycyjnych formach pracy „z alkoholikiem” i jego rodziną. Rodzice często bronią się przed szablonowym wpisaniem w rolę współuzależnionych i skierowaniem do grupy wsparcia dla takich osób. Zresztą postawa taka jest zrozumiała, szczególnie wówczas gdy „pacjentką" bywa starsza, schorowana osoba.

${ }^{12}$ R. Szczepanik, Rodzice..., dz. cyt.

${ }_{13}$ G. Dobińska, A. Cieślikowska-Ryczko, Strategie pracy z rodzicami osób uzależnionych od alkoholu. Perspektywa profesjonalistów, [w:] J. Ratkowska-Pasikowska, D. Müller-Siekierska, K. Walczak-Człapińska (red.), Rodzina w systemie wsparcia i pomocy osobom z problemem alkoholowym, Wydawnictwo Uniwersytetu Łódzkiego, Łódź 2020, s. 106.

${ }^{14}$ R. Szczepanik, Rodzice..., dz. cyt. 
W tej grupie rodziców są tacy, którzy mają uprzednie doświadczenia ingerencji w ich życie rodzinne wielu różnych agend. Można więc powiedzieć, że „zaglądanie” instytucji do wnętrza domu jest już oswojone, a korzystanie z pomocy wpisane w bieg życia danej rodziny i jej kilku pokoleń. Bywa, że w odniesieniu do nałogu najpierw był problem z pijącym ojcem, potem mężem, sobą, a na koniec z dzieckiem, a nawet wnuczkiem. W żargonie niektórych specjalistów pojawia się nawet określenie „łańcuszka rodzinnego” czy „pokoleniowego łańcuszka”15. Rodzinne doświadczenia sprzyjają pewnej łatwości zwracania się do instytucji o pomoc i angażowania instytucji w sprawy rodzinne.

Inaczej jest w przypadku rodziców, którzy są swoistymi „debiutantami” w korzystaniu z pomocy instytucji. Zwykle zgłaszają się po pomoc lub proszą o interwencję instytucji dopiero wtedy, gdy uzależnienie ich dziecka jest już zaawansowane, a konsekwencje szkodliwego picia rozległe i nieodwracalne. Już samo zgłoszenie się do instytucji po pomoc stanowi bardzo negatywne doświadczenie i jest specyficznym punktem zwrotnym w radzeniu sobie ze stygmatyzacją. Bywa, że decyzja o korzystaniu z pomocy ze strony instytucji traktowana jest jako krok desperacki w sytuacji, gdy już wszystko inne zawiodło. Relacje rodziców ze specjalistami przepełnione są paradoksami. Przykładowo zdarza się nierzadko, że rodzice oddają sprawy w ręce instytucji, a następnie utrudniają ich interwencje.

Bardzo często rodzice traktują instytucję specjalistyczną jako kolejną szansę na zdobycie wiedzy o technikach zahamowania problemu alkoholowego (sami specjaliści określają to mianem szukania przez nich „magicznych trików”). Proszą o konkretny plan postępowania i „cudowny lek” na uzależnienie. Najlepiej szybki i skuteczny.

Największe poczucie „bycia w potrzasku” mają rodzice, którzy angażują się w pokonywanie problemów związanych z uzależnieniem od alkoholu swojego dziecka w osamotnieniu. Są wśród nich tacy, którzy korzystali uprzednio z różnych form wsparcia instytucjonalnego, ale porzucili tę pomoc, ponieważ nie spełniła ich oczekiwań, a także ci, którzy nigdy nie upublicznili swoich problemów (stanowią one tajemnicę poliszynela).

Specyficzną cechą tych rodziców jest to, że nie posiadają żadnej przestrzeni, w której mogliby poczuć potwierdzenie swoich działań, rozgrzeszenie oraz gratyfikację. Nie omawiają bowiem swoich dylematów ze specjalistami. Bywa, że dzielą się swoimi problemami tylko z gronem najbliższych osób „zorientowanych” w temacie, ale nie znajdują tu należytego wsparcia z powodu odmiennych podejść do problemu i konfliktu interesów. Najbezpieczniejszą przestrzenią dla ich odreagowania są relacje z tak zwanymi terapeutami życia codziennego (fryzjerzy, sklepikarze itp.) oparte w dużej mierze na poczuciu anonimowości i przelotności relacji.

Osamotnienie rodzica ma charakter fizyczny (jest jednym „opiekunem” problemów dorosłego dziecka) lub symboliczny. W tym drugim przypadku bywa, że ro-

15 Tamże, s. 248 . 
dzice są w związku małżeńskim lub na co dzień mają kontakt z innymi członkami rodziny, którzy są wtajemniczeni w problemy związane z nałogowym piciem danej osoby, Rzecz w tym, że wszyscy podejmują rozproszone działania na rzecz pokonywania kryzysów w rodzinie lub są tacy członkowie rodziny, którzy nie angażują się w pokonywanie kłopotów rodzinnych w ogóle.

Osamotniony rodzic to także taki, którego działania są podważane, kwestionowane lub drugi rodzic „konspiruje” z pijącym alkohol dzieckiem w konsekwencji silnych napięć w obrębie swojej roli („Ojciec wyrzuca go jednymi drzwiami, a matka wpuszcza go innymi”) ${ }^{16}$. Osamotnienie polega więc tu nie tyle na zupełnym braku zasobów, ale na ich rozproszeniu lub nieumiejętnym wykorzystaniu. Siła działania posiadanych zasobów jest ograniczona i ograniczana przez osamotnionego rodzica.

Osamotnionymi rodzicami są ci, których dziecko posiada etykietę „alkoholika” i jest ona na tyle widoczna, że nie ma sensu z nią walczyć. Jeśli jednak rodzice osamotnieni ukrywają problem alkoholowy dziecka, to czynią to $z$ wielu powodów. Jednym $\mathrm{z}$ nich jest lęk przed upublicznieniem związany z ochroną wizerunku dziecka, tak zwanego wysokofunkcjonalnego alkoholika. Warto zauważyć, że ochrona wizerunku niekoniecznie wiąże się ze statusem społeczno-zawodowym dorosłego dziecka. Bywa, że jest to ochrona wizerunku „udanej” czy „porządnej rodziny”.

W obrazie tej grupy rodziców najwyraźniej można dostrzec takie zjawiska, jak koncentrowanie się na ukrywaniu lub kontrolowaniu tajemnicy rodzinnej poprzez minimalizowanie jej widoczności (na przykład usuwanie pijanego dziecka z klatki schodowej) czy pomniejszanie wagi problemu (na przykład przekonanie o piciu jako „tylko” objawie depresji). Działania te w istocie zorientowane są na redukcję szkód powodowanych nałogowym piciem. Jest to często organizowanie minimalnej stabilizacji dziecku, między innymi poprzez troskę o jego „codzienność”, a także zapobieganie degradacji w przyszłości poprzez zabezpieczenie materialnej egzystencji. To drugie polegać może na odpowiednim zarządzaniu majątkiem, by po śmierci rodzica nie dostał się w ręce dziecka pijącego szkodliwie alkohol, które mogłoby na przykład pozbyć się domu (miejsca do mieszkania).

Często bywa jednak, że rodzice świadomie skazują się na osamotnienie w zmaganiu się z nałogiem dziecka. Dzieje się to dlatego, że sami są uzależnieni od wsparcia uzależnionego syna/córki. W takim przypadku jest to świadoma rezygnacja $\mathrm{z}$ interwencji instytucji ze względu na minimalne, ale realne korzyści dla własnej codziennej egzystencji, jakie czerpią z niezaburzonej interwencjami instytucji bliskości z dzieckiem. Nie jest to związane z żadnym psychologicznym uwikłaniem. Jest to rezultat pragmatyzmu życiowego, oszacowania szans na samodzielną egzystencję (brak źródeł wsparcia), wynik bilansu zysków i strat.

Ostatnią grupę rodziców stanowią ci, którzy źródeł siły w pokonywaniu problemu alkoholowego swojego dziecka poszukują w zasobach rodziny. I znajdują je.

16 Tamże, s. 307. 
Oczywiście nie jest to kwestia jedynie wyborów i deklaracji, ale konkretnych warunków, jakie tworzą i posiadają. W odróżnieniu od poprzednio opisanych rodzice ci nie są osamotnieni i działają we wspólnocie, z której też czerpią siły. Wspólnotowość działań rodziny jest możliwa wyłącznie wtedy, gdy wszyscy jej członkowie dysponują wspólnie wypracowaną definicją problemu. Doświadczenia tej ostatniej grupy rodziców stanowią przedmiot rozważań w dalszej części artykułu.

\section{Uwagi metodologiczne}

Perspektywą poznawania i refleksji nad doświadczeniami rodziców (dorosłych) dzieci pijących problemowo alkohol jest paradygmat interpretatywny. Organizację badań, ich przebieg i postępowanie analityczne wyznaczały procedury metodologii teorii ugruntowanej. Kategorią skupiającą analizy było rodzicielskie „radzenie sobie” z problemami, jakie stwarza nałóg dorosłego dziecka. Szczegółowe analizowanie tego „radzenia sobie” polegało na odkrywaniu sposobów definiowania przez badanych rodziców kryzysu powodowanego problemowym piciem alkoholu przez dziecko. Przedmiotem analizy było ponadto rozpoznawanie przez nich, gromadzenie i weryfikowanie zasobów (materialnych, rodzinnych, interpersonalnych, instytucjonalnych) oraz w zależności od tego - rodzaje i przebieg podejmowanych działań w obrębie tak zwanego transferu usług rodzinnych, a także warunki i zakres otwartości na pomoc instytucjonalną.

Ogółem zostało przeprowadzonych kilkadziesiąt wywiadów swobodnych i autobiograficznych z rodzicami, dorosłym rodzeństwem osób pijących alkohol problemowo oraz z przedstawicielami różnorodnych instytucji leczenia odwykowego i poradni zdrowia psychicznego. Pozyskane wyniki badań zostały zaprezentowane w osobnej monografii ${ }^{17}$. Na potrzeby osiągania celu niniejszego artykułu wykorzystano materiał empiryczny, który stanowiły transkrypcje dwóch wywiadów autobiograficznych z rodzicami. W dalszej części artykułu rodzice ci oznaczeni zostali jako A i B. Wybór tych dwóch przypadków rodziców podyktowany był tym, że spośród wszystkich stanowili oni najwyraźniejszą „reprezentację” badanych pod względem sposobu definiowania pokonywania konsekwencji problemowego picia alkoholu za pomocą sił tkwiących w rodzinie (i w jej zaciszu).

I tak, najważniejszą cechą wspólną rodziców A i B, których doświadczenia poddałam analizie, jest to, że stawiali zdecydowany opór przed upublicznianiem i instytucjonalizowaniem problemów związanych $\mathrm{z}$ nadużywaniem alkoholu przez dziecko, które zgodnie określali mianem „rodzinnych”. A (kobieta) mieszkała w wielorodzinnym domu na wsi (w jednym domu z synem, który pił problemowo alkohol). Była wdową i pomagała dziecku w prowadzeniu wspólnego gospodarstwa rolnego. Pijący syn był jednym z kilkorga dorosłych już dzieci. Wszystkie były usamodzielnione

\footnotetext{
17 Tamże.
} 
i miały swoje rodziny. B (mężczyzna) był emerytem podejmującym dodatkową pracę zarobkową. Po rozwodzie zamieszkiwał samotnie, acz utrzymywał z byłą żoną neutralne relacje. On i jego rodzina zamieszkiwali wielkie miasto. Syn problemowo pijący alkohol był jednym z dwojga dorosłych dzieci i zamieszkiwał wspólnie z żoną i dziećmi w innej dzielnicy miasta.

Zarówno A, jak i B mieli bardzo bliskie i poprawne relacje z wszystkimi dziećmi i wnuczkami. Rodzina A cieszyła się uznaniem i dobrą opinią w miejscu zamieszkania. Kobieta była aktywną działaczką w społeczności lokalnej. Ona i rodzina jej syna pozostawali w bardzo dobrych stosunkach z otoczeniem sąsiedzkim. Syn A miał opinię dobrego i nowoczesnego zarządcy swojego gospodarstwa oraz sumiennego pracownika lokalnej firmy. Z kolei syn B cieszył się wysokim uznaniem w swoim środowisku i pełnił istotne funkcje eksperckie (na skalę ogólnokrajową) w dziedzinie zawodowej, którą się zajmował. Synowie A i B nigdy nie korzystali ze specjalistycznych form pomocy i terapii. Oboje mieli za sobą incydentalne doświadczenie z farmakologicznym wsparciem na rzecz przerwania ciągu alkoholowego (detoks i tak zwane wszywki).

Ani w rodzinie A, ani w B nie było wcześniej problemu związanego z uzależnieniami. Nałogowe picie alkoholu w rodzinie było nowym i zaskakującym doświadczeniem. Badana kobieta (A) miała w swoim życiu kontakt $\mathrm{z}$ koleżanką z problemem picia alkoholu i wraz z innymi przyjaciółkami uczestniczyła w dostarczaniu jej pomocy $\mathrm{w}$ procesie wychodzenia $\mathrm{z}$ nałogu. $\mathrm{W}$ trakcie wywiadu charakteryzuje to doświadczenie w kategoriach sukcesu i własnej skuteczności: „[...] miałam koleżankę też, która dzięki mnie wyszła z tego alkoholizmu" [fragm. wywiadu z A].

Oboje rodziców bardzo niechętnie przystąpiło do badań. Niechęć ta była konsekwentnym elementem ich strategii pokonywania kryzysu w rodzinie, którego punktem wyjścia było nieupublicznianie problemów rodzinnych. Co prawda z trudem pozyskano od nich zgodę na udział w badaniach ${ }^{18}$, za to same narracje były niezwykle rozbudowane, a poszczególne rekonstrukcje drobiazgowe i wielowątkowe. Zdecydowanie dawało się odczuć, że opowiadają w sposób całościowy o problemie pierwszy raz. Nie korzystali przecież do tej pory z pomocy żadnej instytucji, z terapii ani nie uczestniczyli w grupach wsparcia i dlatego nie mieli wcześniej przepracowanej opowieści o swoich problemach. Formuła badań (wywiad narracyjny nawiązujący w swoich warunkach do zwykłej rozmowy) niewątpliwie sprzyjał pozyskaniu ich autentycznej opowieści ${ }^{19}$. Nie znaczy to jednak, że wywiady te były zupełnie wolne od tak zwanego zinstytucjonalizowanego języka i żargonu terapeutycznego. W wywiadzie z B dało się wyraźnie odczuć ten rodzaj narracji. Mężczyzna bowiem samodzielnie zdobywał wiedzę specjalistyczną, czytając różne poradniki i broszury poświęcone

${ }^{18}$ Problemy związane z trudnościami badań jakościowych z udziałem rodziców szczegółowo opisane są w książce: R. Szczepanik, Rodzice..., dz. cyt.

${ }^{19} \mathrm{~K}$. Waniek, Lekceważone potencjały i narosłe nieporozumienia: kilka uwag o metodzie autobiograficznego wywiadu narracyjnego Fritza Schützego, „Przegląd Socjologii Jakościowej” 2019, nr 15(2). 
tematyce uzależnień. Ogólnie jednak w wypowiedziach A i B długotrwała, uporczywa i konsekwentna praca z synem opisywana była przez nich za pomocą niespecjalistycznego języka, a wręcz takiego, który przywodził na myśl naiwne, intuicyjne metody wychowawcze, jak namawianie, pouczanie itp.:

I dał się mi w końcu jakoś namówić [fragm. wywiadu z A].

Myślę, że [pauza] że ten, że to, no te, te, te moje, moje [rozbawienie] przestrogi, moje nauki także coś, coś tam dały, no [fragm. wywiadu z B].

\section{Wyniki badań}

Mimo że praca nad neutralizowaniem szkód i hamowaniem rozwoju nałogu dziecka opiera się na zasobach rodzinnych i solidarności wszystkich jej członków, to rodziny A i B różnią się dość znacząco. Rodzina A to grupa z poczuciem silnej odrębności i zamkniętej wspólnotowości. Podczas wstępnej analizy obszernego materiału empirycznego (kilkadziesiąt wielostronicowych transkrypcji) bardzo łatwo dało się wyróżnić ten „typ” chociażby poprzez język narracji kobiety (A), z którą realizowany był wywiad. Kiedy bowiem rekonstruowała działania podejmowane przez tę rodzinę czy prezentowała ustalenia $\mathrm{z}$ „narad” i rodzinnych konsultacji, używała formy „my” („ustaliliśmy”, „postanowiliśmy”, „staramy się, „pojechaliśmy”). Rodzina jest spójna i wspólnie wypracowuje rozwiązania. Co więcej, stawia sprawę na ostrzu noża: nałogowo pijącemu członkowi grozi wykluczenie $\mathrm{z}$ rodzinnych kręgów, jeśli nie podejmie walki z uzależnieniem. Członkowie rodziny zawiązują wyraźny pakt, a uwagę zwracają liczne przykłady solidarności i konsekwencji w obrębie wspólnoty rodzinnej. Matka (A) jest koordynatorką wszystkich działań oraz postacią integrującą rodzinę wokół problemu.

Rodzina B to inny rodzaj układu pozycji i więzi. Rekonstruujący swoje doświadczenia ojciec był rodzinnym wykonawcą zadań na rzecz pokonywania problemu alkoholowego. Otrzymał „zlecenie” (od byłej żony, która zidentyfikowała wraz z synową problem) i podjął działania. Odczytał rodzinne ustalenia i cele (na przykład ukrywanie problemu przed wnuczkami, maskowanie piętna „alkoholika” syna, chronienie go przed problemami w pracy między innymi poprzez dostarczanie alibi), zdobywał i rozwijał samodzielnie wiedzę o uzależnieniu, zbudował plan i go realizował. Cały rodzinny program pracy nad kryzysem opierał się na jego aktywności. Pozostałe osoby wchodziły w role, jakie główny wykonawca/koordynator zlecał do odegrania. Do jego działań należało także podtrzymywanie wśród członków rodziny ustalonej definicji i wypracowanej strategii działań w sytuacji, gdy następowało przeciążenie emocjonalne lub spadek wiary w powodzenie.

Narracje A i B stanowią wyraźnie zamknięte opowieści. Analiza wywiadów zdecydowanie kieruje uwagę na spójność, systemowość działań i specyficzną wiarę w swoją sprawczość. Jest jasne, że rodziny realizują dobrze opracowany i przemyślany plan. 
Z rekonstrukcji wczesnych rodzicielskich doświadczeń wyłaniał się wyraźnie sposób definiowania kryzysu. Kiedy w rodzinie zostało zidentyfikowane i nazwane zagrożenie, szybko doprowadzono do sytuacji, w której sięganie po alkohol zostało zgodnie oznaczone jako „groźne” dla wszystkich członków, nie tylko „alkoholika”. Konfrontowanie się z problemem to jego ujawnienie i nadanie statusu sytuacji, która stanowi zagrożenie dla osoby pijącej i całej rodziny. Być może solidarne uznanie przez wszystkich problemu wiązało się w jakimś stopniu z pojmowaniem „alkoholizmu" jako aberracji. Odkrycie problemu spowodowało także zaskoczenie, a nawet powątpiewanie w jego stałość, na przykład:

Nawet dzieci starsze przecież przyjeżdżały, no przeważnie co niedziela [pauza] i oni nawet sami nie dowierzali, że tak się stało [pauza] z Tomkiem, że tak się rozpił [fragm. wywiadu z A].

Jedno jest pewne - wszyscy członkowie rodziny zgodnie uznali, że pokonywanie nałogowego picia musi przebiegać równolegle ze starannym ukrywaniem problemu przed oczami postronnej publiczności.

To, co istotne, synowie A i B nie deprecjonowali wagi swojego problemu i nie stosowali taktyk neutralizujących ich szkodliwe picie. Wręcz przeciwnie, obsesyjnie bali się ujawnienia ich uzależnienia. Prawdopodobnie więc istotnym warunkiem specyficznego sukcesu rodziców w budowaniu warunków ich synom do pokonywania problemowego picia jest współdzielenie z dziećmi jednakowej definicji kryzysu, który jest do pokonania. Nie znaczy to jednak, że przyznanie się do problemu jest jednoznaczne z jedynie harmonijnymi relacjami ze „wspierającymi” członkami rodziny, a w procesie wychodzenia z nałogu dominują pozytywne emocje oraz panuje ogólna zgoda i mir. Synowie borykający się z brakiem alkoholu negocjują otrzymywane wsparcie i podważają sposób działania rodziny. Przykładowo, matka A opisuje szczegółowo kryzys, z jakim zmagał się syn w procesie porzucania nałogowego picia, i rekonstruowała sięganie po konieczne, drastyczne taktyki reagowania, przyjmujące postać ultimatum i szantażu:

[...] cała rodzina, rodzeństwo mu powiedzieli, ,jak będziesz pił na..., to my Emilkę [córka] wychowamy, a to [pauza] sobie rób, co chcesz" [fragm. wywiadu z A].

Rodzice A i B szczegółowo podają rozległość i charakter strat, jakie mogłyby być udziałem ich dzieci oraz całych rodzin, gdyby problem alkoholowy został upubliczniony. W gruncie rzeczy ich argumentacje oraz lęki całkowicie pokrywają się z problemami charakterystycznymi dla mechanizmów procesów stygmatyzacji ${ }^{20}$. Co prawda w percepcji społecznej alkoholizm jest chorobą, ale jednocześnie zawinioną. Oznacza to, że uzależnienie traktowane jest jako konsekwencja jakichś zaniechań lub

${ }^{20}$ M. Barnard, Drug Addiction and Families, Jessica Kingsley Publishers, London-Philadephia 2007; M. Parchomiuk, S. Byra, Struktura stygmatyzacji przeniesionej u współmałżonków osób z niepetnosprawnością ruchową, „Studia nad Rodziną” 2015, nr 36. 
negatywnych wpływów. Osoby uzależnione ponoszą odpowiedzialność za stan, w jakim się znalazły ${ }^{21}$. I nie tylko one. Naznaczone zostają też całe rodziny „alkoholików”. Dobre cechy żony czy rodzica poddawane bywają w wątpliwość 22 . Jest jeszcze jedno zjawisko. W dominującym medyczno-społecznym podejściu do rozwiązywania problemów alkoholowych akcentowany jest udział agend i specjalistów w procesie pokonywania nałogu. W świadomości społecznej osoba z problemem alkoholowym to uczestnik grup AA, operujący na co dzień samoopisem: „Mam na imię... i jestem alkoholikiem”. Dopiero niedawno do dyskursu naukowego i praktyki terapeutycznej dołączono zagadnienie możliwości pracy nad redukowaniem szkód nałogowego picia i nauką kontrolowanego spożywania alkoholu. Jak piszą Justyna Żulewska-Sak i Katarzyna Dąbrowska:

[...] przekaz społeczny często dotyczy tego, jak poważną, skomplikowaną i trudną chorobą jest uzależnienie, rzadko pokazuje się osoby, które poradziły sobie z tym problemem. I człowiek taki nigdy nie słyszy: „możesz sam rzucić nałóg”, tylko słyszy: „zgłoś się do specjalisty, czeka na ciebie poradnia”23.

Obraz „alkoholika”, który pokonuje swoje uzależnienie samodzielnie i przy wsparciu rodziny, wciąż nasuwa wątpliwości co do powodzenia. Także rodzina, która tworzy warunki dla samoleczenia narażona jest na zarzut o uwikłaniu się w alkoholizm, a poszczególni jej członkowie na etykietę osoby współuzależnionej. Można zaryzykować stwierdzenie, że społeczeństwo (w tym specjaliści tworzący system rozwiązywania problemów dotyczących nadużywania alkoholu) nie jest jeszcze gotowe na traktowanie przestrzeni rodzinnej jako miejsca „samoleczenia” uzależnienia od alkoholu $^{24}$. W tej sytuacji lęk przed negatywną oceną i zarzutami o „nieprofesjonalne” rozwiązywanie problemu może być uzasadniony.

Zasadniczym zasobem rodzinnym A i B jest przepływ komunikacji między wszystkimi aktorami zaangażowanymi w program reagowania. W doświadczeniach obu rodziców wyraźnie odnalazłam także liczne dowody poczucia sprawczości oraz operowania taktykami pozwalającymi na wykorzystywanie zasobów rodziny na rzecz gaszenia kryzysu w zarodku, na przykład:

[Żona] ścisły kontakt ma z żoną syna i tak jak przyjdzie, powiedzmy, pod alkoholem, no to zaraz telefony działają i wie pani, no. I ja, żona, i od razu ja też wiem o tym, no [fragm. wywiadu z B].

[...] na tych chrzcinach znowu syna też tam coś mu się nie podobało, ale zaraz go zwinęły i się mu natłumaczyło [fragm. wywiadu z A].

${ }^{21}$ J. Żulewska-Sak, K. Dąbrowska, Percepcja społeczna czynników udaremniających samodzielne przezwyciężenie uzależnienia - jakościowa analiza porównawcza, „Alkoholizm i Narkomania” 2005, nr 18(3).

${ }^{22}$ R. Szczepanik, Na mapie..., dz. cyt.

${ }^{23}$ J. Żulewska-Sak, K. Dąbrowska, dz. cyt., s. 65.

${ }^{24}$ Zob. J.I. Klingemann, „Ja muszę Pani powiedzieć..., dz. cyt. 
Rodzice rekonstruowali też rozbudowane sposoby podtrzymywania abstynencji czy kontrolowanego picia swojego dziecka i nadawali swoim działaniom znaczenie usuwania „zapalników”. Są to długie fragmenty narracji zawierające rozbudowane dialogi, wyraźnie oznaczony początek kryzysu, jego przebieg oraz rozwiązanie i zakończenie. W przypadku A wymieniani są „wtajemniczeni” członkowie rodziny z przypisaną konkretną rolą (kogoś, kto sprawdza, kogoś, kto jest kierowcą o każdej porze dnia i nocy, kogoś, kto zajmie się dzieckiem itp.). Ilustrację stanowi tu fragment opisu mobilizacji w sytuacji kryzysu związanego z ryzykiem nawrotu i decyzja o zastosowaniu „wszywki”:

[...] powiedział, „mama, ratuj” [...]. To ja niewiele myśląc... syn akurat, mówi, „ja coś tam w polu...”, bo też pracuje, ma gospodarstwo, coś w polu... „ciągnik na polu zostawiłem”, mówi, ,jak telefon dostałem”, mówi, „i w samochód”, to nawet żona nie wiedziała, gdzie jest. Mówi, „,o on? Gdzie on pojechał, ciągnik na polu zostawił”. A mi mówi, „wpadł do domu, przebrał się i mówi, w samochód”, no. I dzwoni potem: „,co się stało, Jacek czy co, czy ten Romek tak wy...”, mówi, wystartował, bo mówi..., no, a, no... [pauza] [fragm. wywiadu z A].

Zasobem, który odnalazłam w przypadkach rodzin A i B było wypracowanie i bezwzględne trzymanie się konsekwentnego reagowania w sytuacji kryzysów oraz specyficzna praca nad emocjonalnym reagowaniem. Praca ta polega głównie na „trzymaniu się planu". W przypadku rodziny B rodzic, na którym opierała się cała rodzinna strategia radzenia sobie z kryzysem, dyscyplinował pozostałych członków, gdy tylko uznał, że brakuje wspólnego frontu działań. Drobiazgowa rekonstrukcja tych doświadczeń przywodziła na myśl znalezienie błędu w oprogramowaniu i usunięcie go. Przykładowo jeśli w rodzinie B ustalono, że wspieranie w nauce kontrolowanego picia oparte będzie na pozytywnych, wzmacniających komunikatach, to emocjonalne reakcje na kryzys, tak zwane awantury domowe, wykraczały poza przyjęty projekt działań.

[...] od razu robić afery, robić takie... a tu taki człowiek potrzebuje tego ciepła, tego... Ja jej [synowej] to już wszystko też tam tłumaczyłem, jak tego, no i [cmoknięcie] też, też z jej strony jest poprawa znaczna przecież. Jest poprawa. Ona to rozumie, ale [zastanowienie] był moment, że ona mówiła, ona się wyprowadzi i tak dalej. Ja mówię, no i co, no i wyprowadzisz się i co, i co zwojujesz, i co zwojujesz? [fragm. wywiadu z B].

Szczególnie drobiazgowo opisywane są przez badanych rodziców wydarzenia kryzysowe (na przykład niekontrolowane picie podczas wielkiej uroczystości), które wymagały uruchomienia wszystkich ról i sił, by daną „akcję” zakończyć dyskretnie i sukcesem. Rodzina A solidarnie znosi uzależnienie swojego członka w ten sposób, że podczas rodzinnych spotkań rezygnuje się z alkoholu lub spożywa się go bardzo symbolicznie.

[...] ciągle mamy, co niedziela, pełne podwórko, bo jak dzieci się zjeżdżają, no to..., nie, nie ma alkoholu, ale jak na przykład jakieś imieniny, święta [pauza], to dostanie kieliszek, dwa i ja...i nie stawiamy. Staramy się nie stawiać alkoholu. 
[pauza] Po kieliszku symbolicznie, „dziękuję”. Wszyscy muszą zrozumieć, że ze względu... Cała rodzina [fragm. wywiadu z A].

„Mówienie jednym głosem” przez wszystkich najbliższych członków rodziny jest charakterystyczne w przypadku A. Jeśli chodzi o rodzinę B, to po zidentyfikowaniu i zdefiniowaniu problemu alkoholowego (jako groźnego, wyraźnego i wymagającego wspólnej pracy nad jego pokonaniem), członkowie rodziny podejmują próby osłabiania wagi niektórych wcześniejszych ustaleń. O ile więc matka A wchodzi w rolę koordynatorki wspólnie ustalonych i podejmowanych działań, to ojciec B staje się kontrolerem i osobą, która rozlicza innych z wykonania zadań (które wcześniej złożono na jego barki). Dla B warunkiem sukcesu w zmaganiu się z kryzysem syna jest nieustanna praca nad całą rodziną i troska o podtrzymywanie przyjętych definicji problemu. B ubolewa, że pozostali członkowie rodziny zbyt szybko uznali zmianę stylu picia syna za sukces i są skłonni przerwać pracę nad wychodzeniem z uzależnienia syna poprzez zbyt pochopną wymianę definicji z picia problemowego na picie „normalne”. Niewątpliwie dostarczanie warunków regeneracji i stabilizacji sprzyjającej kontrolowanemu piciu (lub porzucenia go) powoduje konieczność czujności. Bywa, że to rodzic wchodzi w rolę „ważącego” ilość wypitego alkoholu i dostrzega zagrożenia.

Z wywiadów z A i B w dużej mierze wyłania się obraz syna, który w wyniku pracy nad swoim nałogiem pokonał najgorszy kryzys, uzależnienie jest kontrolowane, na przykład:

[...] kontroluje to. Tak, no na pewno, bo [zastanowienie], bo ja tutaj trochę wtrącę może, to co było kiedyś i co jest teraz, to jest bez porównania, [z naciskiem] bez porównania. Jest o tyle sytuacja w tej chwili [...] dobra, no że, że potrafi się powstrzymać przez jakiś tam, przez dłuższy czas [pauza] i nie pije. Kiedyś było tak, że nie umiał przestać, że potrafił przez kilka dni, 3-4 dni. A w tej chwili nie ma tego. Jest, też jest [cmoknięcie], ale to już nie jest tak, że [zastanowienie], jak to się mówi na umór, bo tak to, wie pani, takie określenie, że napił się na umór, że potrafi się trochę opanować, no [fragm. wywiadu z B].

W wywiadach z tymi rodzicami dało się odczuć energię optymistycznej troski i wiary w sprawczość rodziny. Podczas rekonstruowania różnych wydarzeń, w przejściach pomiędzy poszczególnymi wątkami bywało, że używali pozytywnych samopotwierdzeń swojej skuteczności, na przykład:

Mam nadzieję, że to, [pauza] że będzie dobrze, no [fragm. wywiadu z B].

No i jakoś tak wszystko się układa [...] jest spokojnie [fragm. wywiadu z A].

Podobnych komunikatów nie zawierały żadne wywiady z kilkudziesięciu innych, przeprowadzonych z rodzicami „zinstytucjonalizowanymi” czy osamotnionymi w swoich zmaganiach, mimo że problemowe picie dziecka przyjmowało podobne oblicza i natężenie pod kątem zagrożeń i szkód.

Co zyskali rodzice walczący z nałogowym piciem dziecka w zaciszu rodzinnego domu? W przypadku A można mówić o korzyści, jaką jest sprawdzenie się rodziny 
w kryzysie. Nałogowe picie jednego z synów spowodowało mobilizację wszystkich członków rodziny i silne poczucie sukcesu w postaci ochrony wizerunku i jedności.

W czasie realizowania wywiadów syn A nie pił alkoholu kilka lat i kobieta nie artykułowała kryzysów związanych z ryzykiem powrotu do picia. Nie znaczy to jednak, że "rodzinna sprawa” została zamknięta na zawsze. Była świadoma zagrożeń i specyficzna czujność (ale nie kontrola) stanowiły trwały element relacji z jej synem. $\mathrm{Z}$ drugiej strony kryzys wydawał się zażegnany, a ona sama miała wielkie poczucie zwycięstwa. Dowodem było przyznanie się sąsiadowi do problemu. Czuła się bezpieczna. Kryzys został zażegnany - rodzina pokonała go samodzielnie, odniosła sukces. Można było się pochwalić jej siłą, odpornością i niezłomnością:

[...] sąsiedzi, no [pauza] nie wiedzieli, no. Było wesele sąsiada syna, [pauza] no nie chciał jechać na to wesele. „Za co Tomek nie chce jechać?” No, mówię, „nie chce jechać, bo, mówię, nie będzie....nie chce pić i nie będzie”. [pauza] „No to..., co to", mówi, „przecież nie musi się upijać”, mówi, no tego... Ja mówię, „no... dopiero" ja mówię, „on nie chce jechać, bo nie wolno mu jest pić, a, a tego... [pauza] mówię, a wiadomo, będziecie go zmuszać do wypicia, a on nie chce". [pauza] No i jak powiedziałam temu sąsiadowi, no [...] to mówi, „to ja nie wiedziałem”, mówi, „no kto by pomyślał, że to Tomek”, mówi, „ma takie problemy” [fragm. wywiadu z A].

Inaczej jest w przypadku B. Mężczyzna ma świadomość, że kryzys wciąż trwa, choć pożar został ugaszony. Syn, co prawda, przestał wpadać w wielodniowe ciągi, sięga po alkohol okazjonalnie (zwykle w spotkaniach kuluarowych związanych $z$ pracą). Ojciec nie wierzy w kontrolowane picie i tkwi w nieprzerwanym niepokoju związanym z łamaniem abstynencji przez syna. Jego działania zmieniły jednak cel i natężenie. Wciąż jest koordynatorem rodzinnego reagowania na problem dorosłego dziecka. Nie zarządza już jednak gaszeniem pożaru, który zaskoczył rodzinę i wybuchł z ogromną siłą, ale stoi na straży kontrolowanego picia. Analiza wywiadów pozwoliła dostrzec wyraźnie korzyści w wyniku pracy tego rodzica nad problemem nałogowego picia. Przede wszystkim jest to naprawa relacji ze swoim dzieckiem. Badany rodzic sam dostrzegł to, że w działaniach na rzecz wsparcia syna w pokonywaniu szkodliwego sposobu picia zbliżyli się do siebie. Zaczęli z sobą dużo rozmawiać, wspólnie analizować różne problemy, spontanicznie spędzać więcej czasu. Nigdy wcześniej relacje z synem nie były nacechowane taką bliskością i miłością. Rodzic B zaczął dużo czytać i interesować się problemami społecznymi związanymi z polityką zapobiegania, teoriami naukowymi itp.

\section{Podsumowanie}

Przedstawione analizy nie zmierzają do sformułowania wniosków o znaczeniu tak zwanego autorytetu rodzicielskiego w przebiegu zrywania z nałogowym piciem. Stanowisko specjalistów w tej sprawie jest jasne: nie jest to szczególnie istotny czynnik 
mobilizujący do zmian, a na pewno ważny sam w sobie ${ }^{25}$. Wniosek, który się tu nasuwa jest taki, że znaczenie rodziców jest duże w tworzeniu środowiska wsparcia dla osoby podejmującej walkę z uzależnieniem. Są (albo mogą być) znaczącymi sojusznikami w nauce kontrolowanego sięgania po alkohol oraz sprzyjają regeneracji sił „alkoholika"26, zwłaszcza w sytuacji, gdy z różnych powodów walka z nałogiem odbywa się w zaciszu domu, tj. bez specjalistycznego wsparcia instytucji.

Z przedstawionych tu badań wyłaniają się sylwetki rodziców, którzy identyfikują, gromadzą i wykorzystują zasoby rodzinne w walce z problemowym piciem alkoholu przez dorosłe dziecko. Są to rodzice, którzy nie są osamotnieni w działaniach na rzecz pomocy dziecku. Mają duży i wyraźny kapitał rodzinny, na którym się opierają i z którego czerpią siłę. Nie ma to związku z ich statusem społecznym. Wywiady z rodzicami, których zakwalifikowałam do tej grupy, pochodzą od rodziców, którzy mieli wykształcenie średnie i zawodowe. Tworzą rodziny wielopokoleniowe, ale także są po rozwodzie. Ich „problemowe” dorosłe dzieci zajmują znaczące miejsce w strukturze zawodowo-społecznej w ten sposób, że są osobami publicznymi (mają „wiele do stracenia”), ale też takimi, które prowadzą własną działalność gospodarczą (rolniczą).

Problemy zasygnalizowane w opisie rodziny A i B można oceniać jako zjawiska niepożądane i ryzykowne, jak: lęk przed stygmatyzacją, izolacja społeczna, nieprofesjonalne rozwiązywanie problemów rodzinnych w „czterech ścianach”, zrzucenie odpowiedzialności za zarządzanie pomocą na pojedyncze osoby (rodziców) czy w końcu wadliwa adaptacja do sytuacji przewlekłego stresu powodowanego problemowym piciem alkoholu w rodzinie oraz współuzależnienie. Proponuję jednak przyjęcie pozamedycznej i pozapsychologicznej perspektywy interpretowania doświadczeń rodziców. Pozwala to na wysunięcie innych wniosków niż ocena ryzyka czy rozmiarów współuzależnienia i problemów emocjonalnych związanych z ukrywaniem trudności rodzinnych.

Przyjrzenie się temu, co się dzieje lub co się może stać w takich rodzinach, używając kategorii „efektu ubocznego” (spillover effect) ${ }^{27}$, pozwoli dojrzeć siły, jakie uruchamiają się w sytuacji kryzysu jednego z członków. Należą do nich wysokie poczucie sprawstwa i umiejętność dostrzegania „małych zwycięstw”, konsolidacja rodziny. I mimo że tym, co integruje i wzmacnia wspólnotowość działania rodziny, jest skrywanie tajemnicy (lęk przed stygmatyzacją), to w opisie dwóch przypadków rodzin wyraźnie można dostrzec efekt uboczny, jakim jest rodzinna mobilizacja oraz poprawa relacji, odczucie bliskości, której wcześniej się nie doświadczało, oraz spraw-

${ }^{25}$ Zob. R. Szczepanik, Rodzice..., dz. cyt., s. 297.

26 J.I. Klingemann, Horyzonty zmiany zachowania nałogowego w Polsce, Instytut Profilaktyki Społecznej i Resocjalizacji Uniwersytetu Warszawskiego, Prace Katedry Socjologii Norm, Dewiacji i Kontroli Społecznej, t. XI, Warszawa 2010.

${ }^{27}$ R. Ilies, K.S. Wilson, D.T. Wagner, The spillover of daily job satisfaction onto employees' family lives: The facilitating role of work-family integration, "Academy of Management Journal" 2009, No. 52(1). 
czość. Niezamierzonym (pozytywnym) skutkiem działań rodziców w obrębie rodziny i z użyciem jej sił na rzecz pomocy dziecku problemowo pijącemu alkohol jest także pogłębiona refleksja nad swoim rodzicielstwem oraz - paradoksalnie - poczucie zbliżenia do dziecka i poprawienie $\mathrm{z}$ nim relacji.

\section{Bibliografia}

Barnard M., Drug Addiction and Families, Jessica Kingsley Publishers, London-Philadephia 2007.

Benishek L.A., Carter M., Clements N.T., Allen C., Salber K.E., Dugosh K.L., Psychometric assessment of a self-administered version of the Significant Other Survey, "Psychology of Addictive Behaviors" 2012, No. 26(4).

Cierpiałkowska L., Grzegorzewska I., Dzieci alkoholików w perspektywie rozwojowej i klinicznej, Wydawnictwo Naukowe UAM, Poznań 2016.

Cierpiałkowska L., Ziarko M., Psychologia uzależnień - alkoholizm, Wydawnictwa Akademickie i Profesjonalne, Warszawa 2010.

Dobińska G., Cieślikowska-Ryczko A., Strategie pracy z rodzicami osób uzależnionych od alkoholu. Perspektywa profesjonalistów, [w:] J. Ratkowska-Pasikowska, D. Müller-Siekierska, K. Walczak-Człapińska (red.), Rodzina w systemie wsparcia i pomocy osobom z problemem alkoholowym, Wydawnictwo Uniwersytetu Łódzkiego, Łódź 2020.

Gąsior K., Czynniki zagrażające rozwojowi dzieci w rodzinie z problemem alkoholowym na przykładzie Dorosłych Dzieci Alkoholików, „Alkoholizm i Narkomania” 2008, nr 3.

Grzegorzewska I., Cierpiałkowska L., Pozytywna i negatywna adaptacja dzieci i młodzieży rodziców uzależnionych od alkoholu, „Alkoholizm i Narkomania” 2015, nr 28(4).

Hurcom C., Copello A., Orford J., The family and alcohol: Effects of excessive drinking and conceptualizations of spouses over recent decades, "Substance Use \& Misuse" 2000, No. 35(4).

Ilies R., Wilson K.S., Wagner D.T., The spillover of daily job satisfaction onto employees' family lives: The facilitating role of work-family integration, "Academy of Management Journal" 2009, No. 52(1).

Junik W., Teoretyczne i empiryczne podstawy wzmacniania rezyliencji (resilience) u dzieci z rodzin z problemem alkoholowym, „Dziecko Krzywdzone. Teoria, badania, praktyka" 2012, nr 11(3).

Karasowska A., Krzywdzenie dzieci w rodzinie alkoholowej, „Dziecko Krzywdzone. Teoria, badania, praktyka” 2004, nr 3(3).

Keller P.S., Cummings E.M., Davies P.T., Mitchell P.M., Longitudinal relations between parental drinking problems, family functioning, and child adjustment, "Development and Psychopathology" 2008, No. 20(1). 
Klingemann J., Klingemann H., Czy terapia jest koniecznością? Samowyleczenia a system lecznictwa, [w:] G. Świątkiewicz (red.), Terapia uzależnień - metody oparte na dowodach naukowych, Wydawnictwa Uniwersytetu Warszawskiego, Warszawa 2013.

Klingemann J.I., „Ja muszę Pani powiedzieć szczerze, że o tych problemach to nikt nie wiedział.." Metody badania populacji ukrytych - przykład zjawiska samowyleczenia z uzależnienia, „Prace Instytutu Profilaktyki Społecznej i Resocjalizacji” 2010, nr 16.

Klingemann J.I., Horyzonty zmiany zachowania nałogowego w Polsce, Instytut Profilaktyki Społecznej i Resocjalizacji Uniwersytetu Warszawskiego, Prace Katedry Socjologii Norm, Dewiacji i Kontroli Społecznej, t. XI, Warszawa 2010.

Niewiadomska I., Fel S., Formy przystosowania młodzieży $w$ rodzinie z problemem alkoholowym, „Zeszyty Naukowe KUL” 2015, nr 58(4).

Parchomiuk M., Byra S., Struktura stygmatyzacji przeniesionej u współmałżonków osób z niepetnosprawnością ruchową, „Studia nad Rodziną” 2015, nr 36.

Szczepanik R., Na mapie rodzicielskich doświadczeń: matki i ojcowie osób z piętnem wykolejenia społecznego, „Resocjalizacja Polska” 2021, nr 2.

Szczepanik R., Okólska K., Forgotten parents of alcohol dependent adults. Zapomniani rodzice (dorosłych) dzieci uzależnionych od alkoholu, „Alcoholism and Drug Addiction/Alkoholizm i Narkomania” 2018, nr 31(4).

Szczepanik R., Rodzice osób pijących alkohol problemowo. O ambiwalencji pomocy, Wydawnictwo Uniwersytetu Łódzkiego, Łódź 2020.

Waniek K., Lekceważone potencjały i narosłe nieporozumienia: kilka uwag o metodzie autobiograficznego wywiadu narracyjnego Fritza Schützego, „Przegląd Socjologii Jakościowej” 2019, nr 15(2).

Żulewska-Sak J., Dąbrowska K., Percepcja społeczna czynników udaremniajacych samodzielne przezwyciężenie uzależnienia - jakościowa analiza porównawcza, „Alkoholizm i Narkomania” 2005, nr 18(3).

\section{Family integration by parents of problem drinkers as a way of overcoming crisis}

Abstract: This study concerns overcoming the problems related to alcohol dependence without the intervention of specialist institutions. Research focused on the experiences of parents of adult problem drinkers and the ways in which they use family ties to tackle the problem. Biographical interviews with such parents were analysed drawing on the symbolic interactionist perspective, which allowed the researcher to move beyond medical and psychological approaches. The findings suggest that what brings families together is secrecy (related to fear of stigmatisation). A spillover effect of this secrecy is a sense of agency, improved communication in the family, and greater motivation to tackle the problem. Parents in these situations are found to be more reflective, more aware of their parenting skills and, paradoxically, feel closer to their children.

Keywords: problem drinkers, family, crisis, parents, spillover effect 


\section{About the Author}

Renata Szczepanik - Professor at the Faculty of Educational Sciences of the University of Lodz. Member of the Stanisław Batawia Polish Criminological Society and the Resocialization Pedagogy Team at the Pedagogic Sciences Committee of the Polish Academy of Sciences. Her scientific interests include convict criminology, social rehabilitation, and methodology of field research. 